\title{
Diet, Nutritional Status and School Performance of Schoolchildren in the District of Abidjan: Case of Yopougon and Bingerville
}

\author{
Zahe KYAS $^{1^{*}}$, Méité Alassane ${ }^{1}$, Ouattara $\mathrm{H}^{2}$, Dally $\mathrm{T}^{3}$, Kouame $\mathrm{KG}^{1}$, Aké-Tano $\mathrm{O}^{4}$ and Kati-Coulibaly $\mathrm{S}^{1}$ \\ ${ }^{1}$ Laboratory of Nutrition and Pharmacology, UFR Biosciences, University Félix Houphouët-Boigny, Abidjan, France \\ ${ }^{2}$ UFR Biological Sciences, University Péléforo Gon Coulibaly, Korhogo, France \\ ${ }^{3}$ UFR Environment, University Jean Lorougnon Guédé, Daloa, France \\ ${ }^{4}$ National Institute of Public Health, Abidjan, France
}

*Corresponding author: Zahé KYAS, Nutrition and Pharmacology Laboratory, UFR Biosciences, Félix Houphouët-Boigny University, Abidjan, France, Tel: 571819 13/ 0669 46 27, E-mail: zaheaime@yahoo.fr

Citation: Zahe KYAS, Méité Alassane, Ouattara H, Dally T, Kouame KG, et al. (2017) Diet, Nutritional Status and School Performance of Schoolchildren in the District of Abidjan: Case of Yopougon and Bingerville. J Nutr Health Sci 4(1): 102. doi: 10.15744/2393-9060.4.102

Received Date: December 01, 2016 Accepted Date: March 25, 2017 Published Date: May 12, 2017

\begin{abstract}
Objective: The objective of this study is to assess the relationship between food intake, nutritional status and good school performance among schoolchildren in the district of Abidjan.

Method: A cross-sectional study was carried out from December 2015 to April 2016 in 426 schoolchildren in Yopougon and Bingerville, two communes in the district of Abidjan. The nutritional status was defined starting from the BMI and calculated with Who Anthro Plus v1.0.4. The student and chi-square tests were used to compare the numbers and proportions. Binary and multiple logistic regressions have been used to see the association between good academic performance and the quality of food consumed and socio-demographic characteristics.

Results: The underweight, overweight and obesity affect or 13.6\%, respectively, and $6.8 \%$ of schoolchildren. The proportion of pupils eating fruit and vegetables more than three days in the week (71.42\%) are more likely than their peers consume less than three days in the week (59.22\%). Just as schoolchildren whose parents have been educated are better performing than their peers whose parents were uneducated.

Conclusion: This study did not reveal an association between good academic performance and consumption of fruits and vegetables. But the family environment contributes to better school performance when parents are educated.

Keywords: Diet, nutritional status, good school performance, school children, Abidjan
\end{abstract}

\section{Introduction}

Adolescence is a period during which many teenagers are in schools and take part in several forms of academic activities that impose challenges on their cognitive ability. For these teenagers, their intellectual capacity needs to be enhanced to better respond and perform well [1]. Indeed, school performance expressed by school performance is a multifactorial process conditioned by multiple factors that depend on the child, such as his / her state of health, nutritional and neurocognitive development, and sociodemographic and socio-economic characteristics of the household, the quality and experience of the school [2,3]. But, to enhance cognition as well as the physical development of adolescents, a good amount and quality of food is required. Adolescence is a period of rapid development that requires the ingestion of essential nutrients from foods to cover the harmonious developmental needs of the body. Failure to achieve this demand often results in varying degrees of malnutrition that has an impact on the health and academic performance of adolescents [1]. The association between nutritional status and knowledge of certain sociodemographic and economic characteristics has been the focus of several relevant studies [4]. In Côte d'Ivoire in 2012 reported a prevalence of $39 \%$ lean, $25 \%$ thin and $4 \%$ overweight in a population of 2,038 students with an average age of $12,7 \pm 3.6$ years [5]. Thus, high family size is reported to be associated with malnutrition occurrence [6]. Moreover, the index of population is reported to be correlated positively with the abnormal haematological and martial status [7].

The contribution of diet as a determinant in the academic performance of adolescents has rarely been studied. In Makkah City, reports in the study that students who take breakfast at home are more performant than their counterparts who are not taking or taking it to school $[8,9]$. Adds that teenagers consuming fruits and vegetables more than three times in the week are most likely to have better results. 
Studies on malnutrition in schools have been developed in Côte d'Ivoire, but little data exist on the quality of school food consumption and their relation to school performance. It is in this perspective that this study was carried out to describe the association between food consumption, nutritional status and school performance among schoolchildren aged 8 to 14 years in the Abidjan district.

\section{Materials and Methods}

\section{Study population}

The study population of Yopougon and Bingerville is located in the District of Abidjan. This study involved 426 schoolchildren aged 8 to 14 years. These schools were chosen randomly. Authorization was given by the Ministry of National Education and Technical Education (MENET).

\section{Inclusion Criterion}

Included in this study are students in the 5th and the 6th grade at the time of the survey attending school since the beginning of the current school year.

\section{Exclusion Criterion}

This study excludes children in the 5th and the 6th grade who refused to participate in the survey and those who were absent during the survey period.

\section{Methods}

A cross-sectional survey has been descriptive and analytical taken from December 2015 to April 2016.

\section{Data Collection}

The social demographic and characteristics of the family are now supplemented by the pupil. The information gathered at age, sex, ethnic group, religion, nationality, family size, number of siblings, number of children under 5, rank in the siblings, and the profession of the parents.

\section{Measurement of anthropometric parameters}

Anthropometric measurements were based on the standardized methodology of WHO and the United Nations Children's Fund [10]. The weight was measured using a SOEHNLE electronic weighing scale with a range of $180 \mathrm{Kg}$, an accuracy of $100 \mathrm{~g}$. The size was measured using a locally manufactured measuring rod with an accuracy of $0.1 \mathrm{~cm}$.

All children were weighed in standing position; the child is weighed wearing underwear or light clothing without shoes, with the pockets completely empty.

Young children were measured in a vertical position. Children lean against the toy without shoes, heels joined, legs straight, arms dangling and shoulders relaxed. They look straight ahead, and then lower the headrest perpendicularly to touch the top of the head. Then, the eyes looking perpendicularly at the headrest allow the meter to read.

All these measures were carried out by doctoral students from the nutrition laboratory of UFR Biosciences.

$$
\text { BMI = weight }(\mathrm{Kg}) / \text { height }^{2}\left(\mathrm{~m}^{2}\right)
$$

\section{Classification of nutritional status}

The criteria for the classification of BMI have been defined by WHO for individuals between the ages of 5 and 19 years [11]. These are the latter used in this study.

For a $\mathrm{z}$-score of $\mathrm{BMI}>+1.0 \mathrm{SD}$, the individual is considered overweight whereas for a $\mathrm{z}$-score of $\mathrm{BMI}>+2.0 \mathrm{SD}$, the individual is said to be obese. Individuals with a $\mathrm{z}$-score of BMI between -2 SD to $1 \mathrm{SD}$ are considered normal BMI.

\section{Evaluation of the quality of the feed}

A questionnaire was used to collect data on school feeding practices. This was the frequency of weekly consumption of specifically identified foods. The choice of foods has been guided by their potential impact on food quality, their different effects on nutritional status, their presence in the school environment and their popularity among schoolchildren. Thus, the question asked to students was, during 7 days was: how many days did you eat these foods? These different foods concerned vegetables, fruits, meat, fish, liver, tofu and caramel, candy and chewing gum, biscuits and chocolates, yoghurt and dairy products and sweetened beverages [12]. 


\section{Evaluation of academic performance}

A class assignment is given to the pupils by the teacher, in order to evaluate their levels for the passage to the higher class. Thus, the grade in mathematics was chosen for the assessment of academic performance $[9,13]$.

\section{Statistical analysis}

For statistical analysis, the data were entered and analyzed with the SPSS software (version 20). Nutritional status was calculated with Who Anthro plus v1.0.4. The chi-square test and the t-test were used to compare proportions and averages. Cross-tabulations and chi-square tests were performed between all dependent and independent categorical variables. Multivariate and two variants logistic regressions were used to estimate the odds ratios (OR) with their 95\% confidence interval (CI) and to verify the importance of associations between risk factors and the school performance variable. The statistical significance was represented by a value of $\mathrm{P}<0.05$.

\section{Results and Discussion}

\section{Distributions of children by socio-demographic characteristics}

A total of 426 students from four primary schools participated in this study. This workforce consists of $50.2 \%$ boys and $49.8 \%$ girls. In this population, $44.4 \%$ of schoolchildren live in peri-urban areas and $55.6 \%$ in urban areas. Regarding the size of the household, $78.6 \%$ of the children live in households of more than 5 people. $69.5 \%$ have fewer than 5 siblings and only $0.9 \%$ has more than 10 brothers and sisters. Schoolchildren whose mothers have $49.8 \%$ and $5.9 \%$ have reached a higher level. As for the father's level of education, $26.6 \%$ of the children have their fathers and $21.4 \%$ have reached the upper level (Table 1 ).

\begin{tabular}{|c|c|c|c|}
\hline Variables & Modalities & Frequency & Percentage (\%) \\
\hline \multirow{3}{*}{ Sex } & boys & 214 & 50.2 \\
\hline & girls & 212 & 49.2 \\
\hline & Total & 426 & 100 \\
\hline \multirow{4}{*}{ Age group } & 8 à 10 & 171 & 40.1 \\
\hline & 11 à 12 & 205 & 48.1 \\
\hline & 13 à 14 & 50 & 11.7 \\
\hline & Total & 426 & 100.0 \\
\hline \multirow{3}{*}{ Residential areas } & Urban & 237 & 55.6 \\
\hline & Peri-urban & 189 & 44.4 \\
\hline & Total & 426 & 100.0 \\
\hline \multirow{3}{*}{ Household Size } & $\leq 5$ & 91 & 21.4 \\
\hline & $>5$ & 335 & 78.6 \\
\hline & Total & 426 & 100.0 \\
\hline \multirow{3}{*}{$\begin{array}{l}\text { Number of } \\
\text { siblings }\end{array}$} & $<5$ & 296 & 69.5 \\
\hline & $\geq 5$ & 130 & 30.5 \\
\hline & Total & 426 & 100.0 \\
\hline \multirow{5}{*}{$\begin{array}{l}\text { Mother's } \\
\text { education }\end{array}$} & illiterate & 212 & 49.8 \\
\hline & Primary & 89 & 20.9 \\
\hline & Secondary & 100 & 23.5 \\
\hline & Supérior & 25 & 5.9 \\
\hline & Total & 426 & 100.0 \\
\hline \multirow{5}{*}{$\begin{array}{l}\text { Father's } \\
\text { education }\end{array}$} & Illiterate & 108 & 26.6 \\
\hline & Primary & 79 & 19.5 \\
\hline & Secondary & 132 & 32.5 \\
\hline & Supérior & 87 & 21.4 \\
\hline & Total & 406 & 100.0 \\
\hline
\end{tabular}

Table 1: Social demographic characteristics of schoolchildren

\section{Anthropometric measurements of schoolchildren}

The mean age of the study population is $10.92 \pm 1.32$ years with extremes ranging from 8 to 14 years. This mean age was higher in males $(11.04 \pm 1.30)$ than in females $(10.8 \pm 1.33)$, but no significant differences were observed between these averages $(p=0.068)$. 
The average weight was $35.69 \pm 8.30 \mathrm{~kg}$ with a higher mean weight $(\mathrm{p}=0.017)$ for girls $(36.72 \pm 8.84 \mathrm{Kg})$ than for boys $(34.69 \pm$ $7.62 \mathrm{Kg})$, as the size of the girls $(145.99 \pm 9.35 \mathrm{~cm})$ and that of the boys $(143.82 \pm 13.49 \mathrm{~cm})$. The mean BMI was $16.88 \pm 2.33 \mathrm{Kg} /$ $\mathrm{m}^{2}, 17.24 \pm 2.56$ for girls and $16.53 \pm 2.02 \mathrm{Kg} / \mathrm{m}^{2}$ for boys with a significant difference $(\mathrm{P}=0.002)$ between the two BMI of girls and that of boys (Table 2).

\begin{tabular}{|c|c|c|c|c|}
\hline Variables & $\begin{array}{c}\text { Total population } \\
(\mathbf{N}=\mathbf{4 2 6})\end{array}$ & Girls $(\mathbf{n}=\mathbf{2 1 3})$ & Boys $(\mathbf{n}=\mathbf{2 1 3})$ & P-value \\
\hline Age $($ years $)$ & $10.92 \pm 1.32$ & $10.80 \pm 1.33$ & $11.04 \pm 1.30$ & $0,068^{\mathrm{ns}}$ \\
\hline Height $(\mathrm{cm})$ & $144.98 \pm 9.61$ & $145.33 \pm 10.00$ & $144.49 \pm 9.22$ & $0,415^{\mathrm{ns}}$ \\
\hline Weight $(\mathrm{Kg})$ & $35.69 \pm 8.30$ & $36.72 \pm 8.84$ & $34.69 \pm 7.62$ & $0,017^{\mathrm{s}}$ \\
\hline BMI $\left(\mathrm{Kg} / \mathrm{m}^{2}\right)$ & $16.88 \pm 2.33$ & $17.24 \pm 2.56$ & $16.53 \pm 2.02$ & $0,002^{\mathrm{s}}$ \\
\hline
\end{tabular}

Independent test $\mathrm{t}$ used to compare averages; $\mathrm{N}=$ total population; $\mathrm{n}=$ population; $\mathrm{BMI}=$ Body Mass Index; $\mathrm{ns}=$ not significant at $\mathrm{P}>0.05 ; \mathrm{S}=$ significant a $\mathrm{P}$ to $\mathrm{P}<0.05$

Table 2: Anthropometric measurements of schoolchildren

\section{Distribution of nutritional status of schoolchildren by sex}

The distribution of nutritional status of schoolchildren by sex indicates that excessive or deficiency malnutrition affects both girls and boys. Underweight was present in $13.1 \%$ of boys and $14.2 \%$ of girls; But the difference between these proportions is not significant $(\mathrm{P}>0.05)$. There was no significant difference in the distribution of overweight / obesity in this population ( $>>0.05)$. But there were more girls $(8.0 \%)$ who were affected by this condition than boys (5.6\%). Normal boys (81.3\%) outnumber girls (79.6\%) (Table3).

\begin{tabular}{|c|c|c|c|c|c|}
\hline \multicolumn{2}{|c|}{$\begin{array}{l}\text { Nutritional status (WHO } \\
\text { BMI-for-age Z scores) }\end{array}$} & Boys & Girls & Total & P-value \\
\hline \multirow{3}{*}{ BMI-for- âge } & $\begin{array}{l}\text { Underweight } \\
<-2 \mathrm{SD}\end{array}$ & $28(13.1 \%)$ & $30(14.2 \%)$ & $58(13.6 \%)$ & $0.833^{\mathrm{ns}}$ \\
\hline & $\begin{array}{c}\text { Normal }>-2 \text { SD à } \\
+1 \mathrm{SD}\end{array}$ & $174(81.3 \%)$ & $165(77.8 \%)$ & $\begin{array}{c}339(79.6 \\
\%)\end{array}$ & $0.781^{\mathrm{ns}}$ \\
\hline & $\begin{array}{l}\text { Overweight/ } \\
\text { Obesity }>+1 \mathrm{SD}\end{array}$ & $12(5.6 \%)$ & $17(8.0 \%)$ & $29(6.8 \%)$ & $0.514^{\mathrm{ns}}$ \\
\hline
\end{tabular}

Ns $=$ not significant at $\mathrm{p}>0.05$

Table 3: Nutritional status of the population by sex

\section{Relationship between food intake and academic performance}

The study of the relationship between food intake and academic performance in mathematics indicates that there is no significant difference between fruit and vegetable consumption and good academic performance in mathematics ( $p>0.05$ ). However, the proportion of schoolchildren performing better in mathematics consuming more than three days in the week of fruits and vegetables is higher $(71.42 \%)$ than their counterparts $(59.22 \%)$ who consume less. The proportion of schoolchildren performing well in mathematics, consuming more than three days of milk and dairy products in the week, were more numerous (76.19\%) than those who consumed less (58.76\%). However, no significant difference exists between these different proportions ( $\mathrm{p}>0.05)$. In the case of biscuits and sweetened beverages, there was also no significant difference between the different proportions of schoolchildren consuming more than three days, and their peers who consume less in the week (Table 4).

\begin{tabular}{|c|c|c|c|c|c|c|c|c|}
\hline \multirow[t]{2}{*}{ variables } & \multirow[t]{2}{*}{ Modalities } & \multirow{2}{*}{$\begin{array}{c}\text { frequency } \\
\mathrm{N}^{\circ}\end{array}$} & \multicolumn{2}{|c|}{$\begin{array}{l}\text { Good school } \\
\text { performance }\end{array}$} & \multicolumn{2}{|c|}{ Bivariante logistic regression } & \multicolumn{2}{|c|}{$\begin{array}{c}\text { Multi variante logistic } \\
\text { regression }\end{array}$} \\
\hline & & & $\%$ & $\mathrm{P}$-value & OR (95\%) & $\mathrm{P}$-value & OR (95\%) & P-value \\
\hline \multirow{2}{*}{ Animal Food } & $\leq 3$ days/w & 341 & $203(59.53)$ & \multirow{2}{*}{0.937} & & & & \\
\hline & $>3$ days $/ w$ & 85 & $51(60.00)$ & & $1.020(0.628-1,656)$ & 0,937 & $0.871(0.522-1.453)$ & 0.597 \\
\hline \multirow{2}{*}{$\begin{array}{l}\text { Fruits and } \\
\text { vegetables }\end{array}$} & $\leq 3$ days/w & 412 & $244(59.22)$ & \multirow{2}{*}{0.360} & & & & \\
\hline & $>3$ days $/ \mathrm{w}$ & 14 & $10(71.42)$ & & $1.721(0.531-5.580)$ & 0,365 & $1.624(0.483-5.565)$ & 0.433 \\
\hline \multirow{2}{*}{ cookies } & $\leq 3$ days/w & 363 & $210(57.85)$ & \multirow{2}{*}{0.070} & & & & \\
\hline & $>3$ days/ $w$ & 63 & $44(69.84)$ & & $1,687(0.948-3.004)$ & 0.076 & $1.911(1.039-3.516)$ & 0.037 \\
\hline \multirow{2}{*}{ Legumes } & $\leq 3$ days $/ w$ & 392 & $233(59.44)$ & \multirow{2}{*}{0.791} & & & & \\
\hline & $>3$ days $/ w$ & 34 & $21(61.76)$ & & $1.102(0.536-2.266)$ & 0,791 & $0.908(0.428-1.924)$ & 0.800 \\
\hline \multirow{2}{*}{ Cereals } & $\leq 3$ days/w & 34 & $23(67.64)$ & \multirow{2}{*}{0.320} & & & & \\
\hline & $>3$ days/w & 392 & $231(58.92)$ & & $0.686(0.325-1.447)$ & 0.323 & $0.521(0.238-1.142)$ & 0.103 \\
\hline \multirow{2}{*}{$\begin{array}{l}\text { Milk and dairy } \\
\text { products }\end{array}$} & $\leq 3$ days/w & 405 & $238(58.76)$ & \multirow{2}{*}{0.113} & & & & \\
\hline & $>3$ days/ $w$ & 21 & $16(76.19)$ & & $2.245(0,807-6.249)$ & 0,121 & $2.313(0.804-6.657)$ & 0.120 \\
\hline
\end{tabular}




\begin{tabular}{|c|c|c|c|c|c|c|c|c|}
\hline variables & Modalities & frequency & \multicolumn{2}{|c|}{$\begin{array}{l}\text { Good school } \\
\text { performance }\end{array}$} & \multicolumn{2}{|c|}{ Bivariante logistic regression } & \multicolumn{2}{|c|}{$\begin{array}{l}\text { Multi variante logistic } \\
\text { regression }\end{array}$} \\
\hline \multirow{2}{*}{ Sugary drinks } & $\leq 3$ days/w & 270 & $152(56.30)$ & \multirow{2}{*}{0.065} & & & & \\
\hline & $>3$ days $/ w$ & 156 & $102(65.38)$ & & $1.466(0,975-2.206)$ & 0,066 & $1.539(1.010-2.345)$ & 0.045 \\
\hline
\end{tabular}

$\mathrm{N}$ = number of respondents; Jrs / s = days per week; OR = odds ratio; \% = percentage of schoolchildren performing well in mathematics Table 4: Bivariate and multivariate logistic regressions between good school performance and food

\section{Relationship between good school performance and socio-demographic characteristics}

The proportion of successful schoolchildren with fewer than five siblings is higher $(\mathrm{p}=0.01)$ with a rate of $63.51 \%$ compared with $50.77 \%$ for those with more children. Concerning parental education, a significant association $(p=0.02)$ is observed between the proportion of performing schoolchildren and their fathers in school. Schoolchildren (64.44\%) against (53.47\%) the father of the child. Similarly, the most successful schoolchildren are mothers who have attended school with a rate of $69.60 \%$ against $55.48 \%$ of schoolchildren with illiterate mothers. With a significant difference observed ( $p=0.007)$ between these two groups. As for the place of residence, high-performing schoolchildren living in the peri-urban areas are the most numerous (73.54\%) with a significant difference $(\mathrm{p}<0.001)$. However, the nationality, age, and nutritional status are not significant differences between the different proportions of successful schoolchildren (Table 5).

\begin{tabular}{|c|c|c|c|c|c|c|}
\hline \multirow[t]{2}{*}{ variables } & \multirow[t]{2}{*}{ Modalities } & \multicolumn{2}{|c|}{ Good school performance } & \multirow[b]{2}{*}{ P-value } & \multicolumn{2}{|c|}{ Bivariante logistic regression } \\
\hline & & frequency & $\%$ & & OR $(95 \%)$ & P-value \\
\hline \multirow{2}{*}{ Sex } & Boys & 214 & $123(57.47)$ & \multirow{2}{*}{0.364} & $1.252(0.829-1.891)$ & 0.285 \\
\hline & Girls & 212 & $131(61.79)$ & & & \\
\hline \multirow{2}{*}{$\begin{array}{l}\text { Residential } \\
\text { areas }\end{array}$} & Urban & 237 & $115(48.52)$ & \multirow{2}{*}{0.000} & $2,759(1.773-4.294)$ & 0,000 \\
\hline & Peri-urban & 189 & $139(73.54)$ & & & \\
\hline \multirow{2}{*}{ Nationality } & Ivorian & 308 & $186(60.39)$ & \multirow{2}{*}{0.603} & $1.153(0.715-1.860)$ & 0,560 \\
\hline & Non-Ivorian & 118 & $68(57.63)$ & & & \\
\hline \multirow{3}{*}{ Age group } & 8 à 10 & 171 & $95(55.56)$ & \multirow{3}{*}{0.176} & $2.507(1.219-5.154)$ & 0.012 \\
\hline & 11 à 12 & 205 & $124(60.48)$ & & $1.643(0.816-3.308)$ & 0.165 \\
\hline & 13 à 14 & 50 & $35(70)$ & & & \\
\hline \multirow{2}{*}{$\begin{array}{l}\text { Household } \\
\text { Size }\end{array}$} & $\leq 5$ & 91 & $52(57.14)$ & \multirow{2}{*}{0.586} & $1.298(0.774-2.179)$ & 0.323 \\
\hline & $>5$ & 335 & $202(60.29)$ & & & \\
\hline \multirow{2}{*}{ Siblings } & $<5$ & 296 & $188(63.51)$ & \multirow{2}{*}{0.014} & $0.667(0.417-1.065)$ & 0.090 \\
\hline & $\geq 5$ & 130 & $66(50.77)$ & & & \\
\hline \multirow{2}{*}{$\begin{array}{l}\text { Mather's } \\
\text { education }\end{array}$} & illiterate & 301 & $167(55.48)$ & \multirow{2}{*}{0.007} & $1.543(0.939-2.537)$ & 0.087 \\
\hline & Primary and more & 125 & $87(69.6)$ & & & \\
\hline \multirow{2}{*}{$\begin{array}{l}\text { Father's } \\
\text { education }\end{array}$} & illiterate & 187 & $100(53.47)$ & \multirow{2}{*}{0.022} & $1.221(0.772-1.932)$ & 0.397 \\
\hline & Primary and more & 239 & $154(64.44)$ & & & \\
\hline \multirow{3}{*}{ BMI } & underweight & 58 & $33(56.90)$ & \multirow{3}{*}{0.889} & $0.897(0.344-2.340)$ & 0.825 \\
\hline & Normal & 339 & $204(60.17)$ & & $0.823(0.363-1.869)$ & 0.642 \\
\hline & Overweight / Obesity & 29 & $17(58.62)$ & & & \\
\hline
\end{tabular}

$\mathrm{N}=$ number of respondents; $\mathrm{BMI}=$ body mass index for age; $\mathrm{OR}=$ Odds Ratio; $\mathrm{P}$-value is significant at $\mathrm{p}<0.05$ Table 4: Multivariate logistic regression between school performance and socio-demographic characteristics of schoolchildren in Yopougon and Bingerville $(\mathrm{N}=426)$

\section{Discussion}

The average age of schoolchildren was $10.92 \pm 1.32$ years in this study, and is approximately the same as the study population of on predisposing, facilitating and enhancing food consumption factors health and non-health among schoolchildren in Ouagadougou [12].

The assessment of nutritional status has shown that malnutrition is present in this population. Slimness and overweight / obesity were respectively $13.6 \%$ and $6.8 \%$. The prevalence of overweight / obesity is similar to that shown in Indian schoolchildren aged between 6 and 11 years [10]. But it is lower than that found by among Ivorian students whose average age were $12 \pm 3.6$ years [5]. This difference could be explained by the presence of obesogenic foods in the environment of Ivorian schoolchildren. It could be the case of Nigerian children, which were $22.9 \%$ and Indians, which were $26.5 \%$ [14,15].

The association between food consumption and school performance was not observed in this work. Yet, the most successful schoolchildren were those consuming more fruits and vegetables, as well as milk and dairy products compared to their peers. On 
the other hand, a significant association was observed between fruit and vegetable consumption among schoolchildren in Canada and in the Gaza Strip [3,9]. Fruits and vegetables have a key role in nutritional balance. They are the main food sources of fiber, vitamins, minerals and other biological components for the growth of the organism [16]. In this study, we investigated the effects of a number of pathologies on childhood [17].

School performance is independent of the nutritional status of schoolchildren defined from BMI. These data are consistent with, which is a significant relationship between nutritional status and academic achievement $[9,13]$. On the other hand, the nutritional status measured by the importance of the micronutrients indicated a strong association on the cognitive capacity of the students or better academic performance [18]. This may justify the relationship between academic performance and nutritional status in this study because schoolchildren would always be present at school and assumed to be in good health. Also, claims that take breakfast enhance health and academic performance, when it is specifically composed of quality nutrients [19]. Statistical analysis of the results of a positive association between good academic performance and certain socio-demographic characteristics, such as siblings, father and mother education. These results corroborate those of who found a positive association between academic performance and parental education [9].

Children, whose parents had a high level of education, can reach a high school or a university, performed better compared to their equivalents whose parents were uneducated [20].

These data highlight the family environment on academic performance. On the other hand, the size of the household and the age of schoolchildren on school performance were not confirmed in this study.

One of the limitations of this study is that the interview focused only on the children and not the mothers of the households. It was therefore unable to measure children's food intake in order to really find the relationship between quality and quantity of food consumed and school performance.

\section{Conclusion}

The mean age of the study population is $10.92 \pm 1.32$ years. This population is mainly from a neighborhood and an urban area of the district of Abidjan. The prevalence of underweight, normal, and overweight / obesity is $13.6 \%, 79.6 \%$ and $6.8 \%$ of schoolchildren, respectively. Food consumption was not associated with school performance. But the most successful schoolchildren were those who consumed more fruits and vegetables and more milk and dairy products. Similarly, nutritional status did not reveal any association on academic performance. The results of this study are presented in this paper.

\section{Acknowledgment}

I would like to express my sincere gratitude to the teaching staff and to the students of the different schools where this data has been collected. Specially, I would like to thank PhD students Djetouan Kacou, Kouakou Firmin who contributed to the survey.

\section{References}

1. Ogunsile SE (2012) The Effect of Dietary Pattern and Body Mass Index on the Academic Performance of In-school Adolescents. International Education Studies 5: 65-72.

2. EL Hioui M, Soualem A, Ahami AOT, Aboussaleh Y, Rusinek S, et al. (2008) Caractéristiques sociodémographiques et anthropométriques en relation avec la performance scolaire dans une école rurale de la ville de Kenitra (Maroc). Antropo 17 : 25-33.

3. Considine G, Zappala G (2002) The influence of social and economic disadvantage in the academic performance of school students in Australia. J Sociol. 38: 129-148.

4. Florence MD, Asbridge M, Veugelers PJ (2008) Diet quality and academic performance. J Sch Health 78: $209-215$.

5. KE Kramoh, YNK N'goran, E AKE-Traboulsi, BC Boka, DE Harding, et al. (2012) Prévalence de l'obésité en milieu scolaire en Côte d'Ivoire. Annales de cardiologie et d’angéiologie 61: 145-149.

6. Bleyere NM, Kokore AB, Konan BA, Yapo AP (2013) Prevalence of child malnutrition through their anthropometric indices in school canteens of Abidjan (Côte d'Ivoire). Pakistan journal of nutrition 12: 60-70.

7. Atto V, Bléyéré MN, Konan AB, Datté JY, Yapo PA (2013) Depletion of iron stores and main associated parameters in adolescents of Côte d'Ivoire. Pakistan Journal of Nutrition 12: 188-196.

8. Bukhari HM (2013) Anthropometric Measurements and the Effect of Breakfast Sources in School Achievement, Physical Activity and Dietary Intake for 6-13 Years Old Primary School Children Girls in Makkah City. International Journal of Nutrition and Food Sciences 2: $272-279$.

9. Abudayya, Z Shi, Y Abed, G Holmboe-Ottesen (2011) Diet, nutritional status and school performance among adolescents in Gaza Strip. EMHJ 17: 218-225.

10. OMS (1995) Utilisation et interprétation de l’anthropométrie. Genève: Organisation Mondiale de la Santé. Rapport d’un comité d’expert. Nº54 : 508.

11. Onis DM, Onyango AW, Borghi E, Siyam A, Nishida C, et al. (2007) Development of a WHO growth reference for school-aged children and adolescents. Bull World Health Organ 85: 660-667.

12. Daboné C, Delisle H, Receveur O (2013) Predisposing, facilitating and reinforcing factors of healthy and unhealthy food consumption in schoolchildren: a study in Ouagadougou, Burkina Faso. Glob Health Promot 20: 68-77.

13. Ateillah K, Aboussaleh Y, Rachid S, Ahami S, (2012) Evaluation nutritionnelle et son impact sur la performance scolaire des écoliers ruraux de la région de sidi Taybi dans la province de Kenitra (MAROC). Antropo 28: 71-76. 
14. Essien E, Haruna MJ, Emebu PK (2012) Prevalence of malnutrition and its Effects on the academic performance of students in some selected secondary schools in sokoto metropolis. pakistan journal of nutrition, 11: 511-515.

15. Amruth M, Kumar S, Kulkarni AG, Kamble SV, Ismail IM. (2015) A study on nutritional status and morbidity pattern among primary school children in Sullia town, South India. Indian Journal of Basic and Applied Medical Research 4: 100-112.

16. PNNS (2009) Livret d'accompagnement du guide nutrition des enfants et des ados pour tous les parents destiné aux professionnels de santé 153.

17. Kazi M Jamil, Ahmed Shafiqur Rahman, PK Bardhan, Ashraful Islam Khan, et al. (2008) Micronutrients and Anaemia. J Health Popul Nutr 26: $340-355$.

18. Best C, Neufingerl N, Rosso JMD, Transler C, Briel TVD, Osendarp S (2011) Can multi-micronutrient food fortification improve the micronutrient status, growth, health, and cognition of schoolchildren? A systematic review. Nutrition Reviews 69: 186-204.

19. Murphy JM (2007) Breakfast and learning: An updated review. Current Nutrition \& Food Science 3: 3-36.

20. Lee YY, Wan AMWM (2014) Mutritional status, academic performance and parental feeding practices of primary school children in a rural district in Kelantan, Malaysia. Prog Health Sci 4: 144-152.

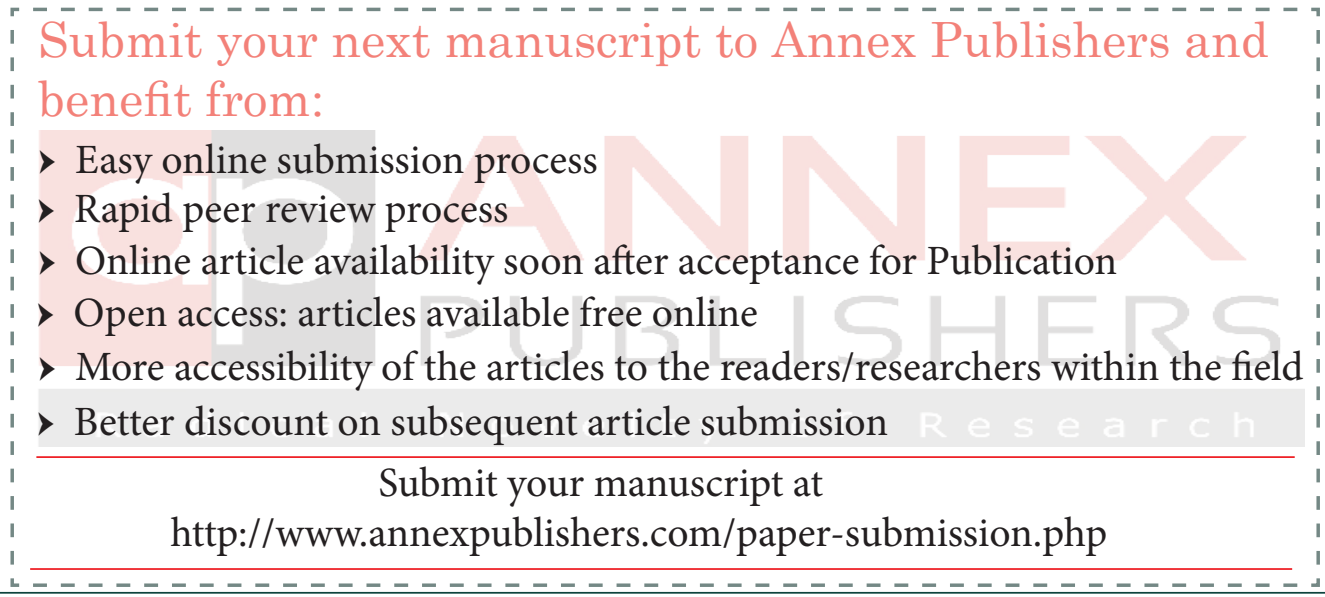

